\title{
PENDIDIKAN AGAMA HINDU BERBASIS KEARIFAN LOKAL KAHARINGAN MELALUI MATA KULIAH TAWUR DI SEKOLAH TINGGI AGAMA HINDU NEGERI TAMPUNG PENYANG PALANGKA RAYA
}

\author{
Oleh: \\ I Komang Widyana \\ Institut Agama Hindu Negeri Tampung Penyang, Palangkaraya \\ komangwidnyana@gmail.com
}

\begin{abstract}
STAHN-TP Palangkaraya really understands the potentials of the local wisdom of the Kaharingan community in Kalimantan in designing and implementing a curriculum with the local character as the support of the general curriculum as found in all the Hindu universities in Indonesia. The characterized curriculum includes seven subjects related to the local wisdom of Kaharingan. It is implemented to the Hindu education program in STAHN-TP Palangka Raya. The local content in STAHN-TP Palangka Raya is the subject which has correlation with the local wisdom or the teachings and the tradition of the Dayak Kaharingan. The subject includes materials as Panaturan, Tawur, Tandak, Sangiang Language, Agara Agama Hindu Kaharingan, Local Language (Dayak Ngaju), and Hindu Theology of Kaharingan.
\end{abstract}

Keywords: local wisdom, Kaharingan, local characterized curriculum, tawur subject

\begin{abstract}
Abstrak
STAHN-TP Palangka Raya memahami terhadap potensi kearifan lokal Kaharingan di Kalimantan, dalam merancang dan mengimplementasikan suatu kurikulum penciri (lokal) sebagai pendamping kurikulum umum seperti pada Perguruan Tinggi Hindu di Indonesia. Kurikulum penciri tersebut melahirkan tujuh mata kuliah lokal Kaharingan yang dilaksanakan pada pendidikan agama Hindu di STAHN-TP Palangka Raya. Isi dari muatan lokal di STAHN- TP Palangka Raya adalah mata kuliah yang berkaitan dengan kearifan lokal atau ajaran dan tradisi Dayak Kaharingan. Mata kuliah tersebut yaitu Panaturan, Tawur, Tandak, Bahasa Sangiang, Acara Agama Hindu Kaharingan, Bahasa Daerah (Dayak Ngaju), Dan Theologi Hindu Kaharingan.
\end{abstract}

Kata kunci: kearifan lokal, kaharingan, kurikulum penciri lokal, mata kuliah tawur

\section{PENDAHULUAN}

Sejak zaman dahulu kala dalam sistem pendidikan spiritual, masyarakat Dayak Kaharingan telah mengenal sistem parampara di India yang sesuai dengan perspektifnya. Sebelum masa kemerdekaan masyarakat Dayak Kaharingan di Kalimantan Tengah dalam proses pembelajaran spritual umumnya menyimak pengetahuan dari guru atau tetua berupa tutur/ cerita. Maksudnya, masyarakat Dayak Kaharingan dalam proses pembelajaran mengenai hal spritual, etika, adat istiadat, upacara dan sebagainya memberikan pengetahuan secara lisan kepada generasi muda atau anggota masyarakat. Kaharingan sejak 
berintegrasi dengan agama Hindu secara de jure pada tahun 1980 mulai menggunakan metode tulisan dalam pendidikan agama Hindu berbasis kearifan lokal Kaharingan berupa kitab Panaturan dan kitab tawur bagi umatnya.

Albert Einstein (1879-1955) menyatakan bahwa "religion without science is blind and science without religion is paralyzed" (agama tanpapengetahuan adalah buta dan pengetahuan tanpa agama adalah lumpuh). Senada dengan hal tersebut menurut Kadir, dkk (2012: 81) Fungsi utama pendidikan mengembangkan kemampuan dan membentuk watak, kepribadian serta peradaban yang bermartabat dalam hidup dan kehidupan atau dengan kata lain pendidikan berfungsi memanusiakan manusia, agar menjadi manusia yang benar sesuai dengan norma yang dijadikan landasannya. Manusia dalam menjalani kehidupannya sehari-hari selayaknya selalu berlandaskan dharma.

Negara dalam hal ini Dewan Perwakilan Rakyat Republik Indonesia (DPR RI) telah membuat dan mengatur dengan baik landasan yuridis tentang pendidikan dan pendidikan keagamaan bagi seluruh rakyat Indonesia. Hal tersebut tercantum dalam Undang-Undang Republik Indonesia Nomor 20 Tahun 2003 tentang Sistem Pendidikan Nasionalpada pasal 1 ayat 1 yang menyebutkan bahwa:

Pendidikan adalah usaha sadar dan terencana untuk mewujudkan suasana belajar dan proses pembelajaran agar peserta didik secara aktif mengembangkan potensi dirinya untuk memiliki kekuatan spiritual keagamaan, pengendalian diri, kepribadian, kecerdasan, akhlak mulia, serta keterampilan yang dibutuhkan bagi dirinya, masyarakat dan bangsa.

Berdasarkan kutipan tersebut, selayaknya pendidikan membimbing manusia menuju pengetahuan material dan rohani yang seimbang. Mahatma Gandhi (18691948) menyatakan bahwa "education without character is useless" (pendidikan tanpa karakter adalah sia-sia). Maksudnya, bahwa pendidikan selayaknya mampu mengarahkan manusia menjadi lebih baik (memanusiakan manusia). Pendidikan juga selayaknya membentuk dan mengembangkan karakter manusia kearah yang lebih baik. Singkatnya, pendidikan seutuhnya harus manusiawi tidak hanya berfokus pada pendidikan intelektual semata, tetapi juga kehalusan budi dan disiplin bathin bagi seluruh rakyat Indonesia. Senada dengan itu Peraturan Pemerintah No. 55 tahun 2007 menjelaskan bahwa:

Pendidikan keagamaan adalah pendidikan yang mempersiapkan peserta didik untuk dapat menjalankan peranan yang menuntut penguasaan pengetahuan tentang ajaran agama dan/atau menjadi ahli ilmu agama dan mengamalkan ajaran agamanya.

Berdasarkan kutipan tersebut, pendidik berkewajiban untuk memberikan pelayanan, bantuan, bimbingan, dan pengaruh dalam bentuk ilmu pengetahuan agama Hindu berdasarkan ajaran Weda. Peserta didik yang beragama Hindu khususnya di Kalimantan Tengah, perlu menumbuh kembangkan potensi yang dimilikinya secara intensif dan berlandaskan pada kearifan lokal Kaharingan. Sehingga mereka tidak kehilangan jati diri sebagai masyarakat Dayak yang beragama Hindu dengan kearifan lokal yang beragam dan unik.

Akan tetapi pemahaman umat Hindu tentang ajaran agamanya, saat ini belum mengalami peningkatan yang signifikan khususnya di Kalimantan Tengah. Fenomena yang terjadi karena dalam kurun waktu yang cukup lama (1940-1980-an) umat Hindu kurang mendapatkan pendidikan dan pembinaan keagamaan yang berkelanjutan. Pembinaan yang dilakukan oleh lembaga keagamaan Hindu atau organisasi masyarakat lebih banyak pada aspek ritual. Aspek pendidikan Hindu secara formal cukup memuaskan, tetapi perlu peningkatan pada aspek informal dan non formal.

Sering dijumpai juga praktik-praktik keagamaan yang kurang sesuai dengan kondisi nyata sosial masyarakat dan menyimpang dari nilai-nilai ajaran Hindu yang sesungguhnya. Manusia tidak cukup hanya mengetahui ilmu agama, tetapi perlu meresapi dan memahami kebenaran-kebenaran yang termuat pada sloka/ ayat kitab suci dan dapat diterjemahkan pada kondisi nyata masyarakat seharihari. Agama merupakan pedoman praktik dan disiplin manusia dalam menjalani kehidupan sosialreligius. Beragama bukan hanya di tempat suci atau di hari tertentu semata, tetapi dimanapun, kepada siapapun dan kapanpun. Manusia dalam mengarungi kehidupan di dunia ini dan bukan 
hanya tahu akan pengetahuan ajaran agama Hindu. Manusia juga selayaknya meimplementasikan ajaran tersebut dalam kehidupan sesuai dengan jaman dan situasi.

Pendidikan Agama Hindu pada masyarakat Dayak di Kalimantan Tengah, sejak tahun 1980an hingga saat ini cukup memuaskan. Berdasarkan dari data statistik yang dihimpun dari dokumen Sekolah Tinggi Agama Hindu Negeri Tampung Penyang (STAHN-TP) Palangka Raya, umat Hindu etnis Dayak (Hindu Kaharingan) yang sedang/telah menempuh jenjang pendidikan D.II, D.III ( tahun 1980-an hingga 2001), S1, dan S2 (2001-sekarang) berjumlah \pm 1000 mahasiswa dan alumni. Namun, dari segi kualitas belum mengalami peningkatan yang signifikan. Hal ini berdasarkan dari tingkatpemahaman umat Hindu Kaharingan tentang ajaran agama Hindu (umum dan lokal Kalimantan Tengah) yang belum maksimal.

Kemudian, umat Hindu Kaharingan di kota Palangka Raya dan daerah lainnya di Kalimantan Tengah sering mengalami diskriminasi dari umat lain berupa hinaan, dan yang paling meresahkan yaitu adanya konversi agama yang dilakukan oleh misionaris serta ajakan/sugesti dari umat lain di Kalimantan Tengah. Namun demikian, berbagai tindakan tersebut yang ditujukan kepada umat Hindu Kaharingan telah lama berlangsung hingga saat ini. Sering kali terjadi klaim atas tradisi berupa upacara sakral Hindu Kaharingan oleh beberapa oknum masyarakat. Karena upacara tersebut adalah adat istiadat dan tidak termasuk upacara agama Hindu. Hal tersebut sangat meresahkan umat Hindu Kaharingan, sehingga perlu adanya komunikasi yang baik antara kedua belah pihak.

Sekolah Tinggi Agama Hindu Negeri Tampung Penyang Palangka Raya (STAHN-TP) adalah satu-satunya perguruan tinggi Hindu yang berada di pulau Kalimantan. STAHN-TP Palangka Raya memiliki corak Hindu lokal Kalimantan Tengah yang sangat khas yaitu mengadopsi ajaran dan tradisi kearifan lokal Kaharingan, jika dibandingkan dengan Perguruan Tinggi Hindu lainnya di Indonesia. STAHN-TP Palangka Raya juga memiliki dua komponen mata kuliah agama Hindu yaitu mata kuliah inti dan mata kuliah lokal. Mata kuliah inti terdiri dari tattwa, Weda, dharma gita, Purana, Itihasa, bahasa Sansekrta, bahasa Kawi, Ayurweda, yoga, Upanisad, hukum Hindu, dan darsana yang digunakan pada proses pendidikan agama Hindu di STAHN-TP Palangka Raya, seperti pada Perguruan Tinggi Hindu lainnya di Indonesia. Sedangkan mata kuliah lokal memiliki ciri khas dalam proses pendidikan agama Hindu yaitu memuat tradisi lokal Kalimantan Tengah. Tujuh mata kuliah lokal tersebut yaitu Panaturan, tawur, tandak, bahasa Sangiang, acara agama Hindu Kaharingan, bahasa daerah (Dayak Ngaju) dan theologi Hindu Kaharingan. Mata kuliah tersebut sesuai dengan buku pedoman pelaksanaan pendidikan agama Hindu di STAHNTP Palangka Raya untuk melestarikan tradisi Hindu Kalimantan Tengah.

Tawur sebagai suatu mata kuliah lokal di STAHN-TP Palangka Raya memiliki ciri khas tersendiri, jika dibandingkan dengan mata kuliah pada perguruan tinggi Hindu lain di Indonesia. Pada hakikatnya mata kuliah tersebut memuat tata cara upacara Tawur yang dilakukan oleh umat Hindu Kaharingan di Kalimantan Tengah. Mata kuliah Tawur merupakan penghubung utama mata kuliah lainnya seperti acara agama Hindu Kaharingan, Tandak, dan Panaturan.

Pelaksanaan pendidikan agama Hindu berbasis kearifan lokal Kaharingan melalui mata kuliah Tawur kepada mahasiswa di STAHN-TP Palangka Raya, tidak selamanya berjalan dengan lancar. Karena mahasiswa STAHN-TP Palangka Raya berasal dari daerah atau Daerah Aliran Sungai (DAS) yang beragam di wilayah regional Kalimantan. Hal ini membuat tradisi agama Hindu yang dibawa oleh mahasiswa memiliki ciri khas tersendiri yang tidak dimiliki daerah lain, sehingga dapat menimbulkan "konflik" dalam pikiran mereka. Mahasiswa juga beradaptasi dengan tradisi lokal agama Hindu di Kota Palangka Raya. Kearifan lokal Kaharingan yang dilaksanakan pada proses pendidikan di STAHN-TP Palangka Raya, lebih banyak memuat tradisi yang berasal dari DAS Kahayan, Kapuas, dan Katingan. Berdasarkan fakta bahwa mahasiswa STAHN-TP juga berasal dari DAS lainnya, contoh DAS Barito. Kendala tersebut membuat mahasiswa etnis Dayak yang tidak berasal dari DAS Kahayan, Kapuas, dan Katingan mengalami kesulitan dalam menjalani proses pendidikan Agama Hindu di STAHN-TP Palangka Raya. Mahasiswa STAHN-TP Palangka Raya yang berasal selain dari DAS Kahayan,

Katingan, dan Kapuas terkadang kurang 
mengenal ajaran-ajaran agama Hindu Kaharingan yang berasal dari kitab Panaturan. Biasanya mereka dalam melaksanakan persembahyangan cenderung menggunakan kitab Bhagawadgita dan Sarasamuccaya sebagai panduan. Tradisi umat Hindu etnis Dayak memiliki keberagaman yang khas, sehingga dalam merumuskan isi materi ajar muatan lokal Kaharingan di STAHN-TP Palangka Raya mengalami kesulitan. Bebeberapa pihak seperti mahasiswa dan dosen yang ikut serta dalam kegiatan kampus, contohnya seminar, kegiatan UKM (Unit Kegiatan Mahasiswa), pengabdian masyarakat, dan lain-lain. Mereka menginginkan tradisi lokal keagamaannya untuk diangkat dan diadopsi ke dalam kurikulum muatan lokal

Kaharingan STAHN-TP Palangka Raya. Kearifan lokal Kaharingan di Kalimantan Tengah sangat kaya dan berasal dari DAS yang beragam serta memiliki keunikan tersendiri. Selayaknya dengan adanya potensi tradisi keagamaan yang beragam di setiap DAS di Kalimantan, mahasiswa dari etnis Dayak yang berbeda tradisi memiliki kesempatan yang sama untuk mengetahui, mempelajari, melestarikan, dan mengenalkan tradisi leluhur kepada khalayak luas.

Mahasiswa STAHN-TP Palangka Raya juga mengalami kesulitan untuk mendapatkan buku pedoman yang berkaitan dengan mata kuliah lokal Kaharingan khususnya Tawur. Buku yang tersedia di toko buku atau perpustakaan di wilayah Kalimantan Tengah langka atau bahkan tidak ada, buku yang memenuhi kriteria tersedia hanya di internal kampus, contohnya di perpustakaan STAHN-TP Palangka Raya. Ketika mahasiswa ingin memiliki buku pedoman tersebut untuk menambah pengetahuan dan memenuhi kewajiban yang diberikan dari dosen, hanya diperbolehkan meminjam di perpustakaan. Para dosen STAHN-TP Palangka Raya dan khususnya dosen mata kuliah lokal pun 'bersaing' dengan mahasiswa untuk memiliki buku tersebut. Penulis melakukan penelitian mengenai pendidikan agama Hindu berbasis kearifan lokal Kaharingan melalui mata kuliah Tawur di Sekolah Tinggi Agama Hindu Negeri Tampung Penyang Palangka Raya.

\section{PEMBAHASAN}

\subsection{Kegiatan Pembelajaran Mata Kuliah Tawur}

Pelaksanaan pembelajaran pada jenjang Perguruan Tinggi relatif sama dengan jenjang pendidikan lainnya. Karena, kegiatan pembelajaran adalah interaksiilmu pengetahuan tiga arah yaitu antara pendidik, peserta didik dan sesamanya yang berlangsung secara intensif dalam suatu mata pelajaran/kuliah. Pengetahuan dan pengalaman yang dimiliki oleh mahasiswa sebagai individu yang dinamis, tidak dapat disamakan dengan juniornya di jenjang TK, SD, SMP, dan SMA. Mahasiswa sebagai peserta didik pada jenjang Perguruan Tinggi dianggap telah dewasa dalam mengetahui, memahami, dan mengimplementasikan setiap materi pembelajaran yang diberikan oleh dosen. Jadi, dosen berperan sebagai fasilitator dalam proses pembelajaran di ruang kelas. Karena itu, mahasiswa dituntut untuk lebih berperan aktif dalam mengeksplorasi pengetahuan di kampus dan di luar kampus.

Mahasiswa dalam mengeksplorasi suatu ilmu pengetahuan tidak hanya didapatkan dari bangku perkuliahan, lingkungan masyarakat juga mempunyai peran penting dalam membangun pengetahuan dan pengalaman mahasiswa. Contohnya, pada pelaksanaan KKN (Kuliah Kerja Nyata) dan pengabdian pada masyarakat mahasiswa dituntut untuk memberikan pengetahuan yang didapat dari kampus dan belajar membaur kepada masyarakat sekitar, sesuai dengan bidang keahlian yang dimiliki. Implikasinya adalah mahasiswa mendapatkan pengetahuan dan pengalaman baru yang didapatkan dari lingkungan masyarakat sekitar, dengan berbagai kebudayaan, dan lain-lain. Kemudian, pengetahuan dan pengalaman tersebut sebagai modal mahasiswa dalam menuntut pendidikan di Perguruan Tinggi.

Menurut Sagala (2010: 64) aktivitas pembelajaran dapat berupa interaksi belajarmengajar dalam suasana edukatif, yaitu interaksi yang sadar akan tujuan. Interaksi yang telah ditetapkan untuk suatu tujuan tertentu adalah pencapaian tujuan pembelajaran yang telah dirumuskan pada satuan pelajaran. Berdasarkan dari uraian tersebut, dosen pengampu mata kuliah lokal Kaharingan dan pimpinan STAHNTP Palangka Raya (bidang kurikulum) menyadari terhadap potensi yang dimiliki oleh umat Hindu 
Kaharingan yang memiliki ajaran dan tradisi beragam setiap DAS di Kalimantan. Karena letak geografis STAHN-TP Palangka Raya berada di DAS Kahayan, Kalimantan Tengah. Maka, pencapaian tujuan pembelajaran yang telah dirumuskan pada satuan pelajaran atau kurikulum, menyesuaikan dengan ajaran dan tradisi DAS Kahayan.

Kemudian, Puspe (2011: 84) memaparkan bahwa proses pembelajaran akan berjalan dengan baik, jika terjalin dialog atau interaksi antara pendidik dan peserta didik. Puspe melanjutkan, dosen tidak hanya berperan sebagai fasilitator dan sekedar memberi pengetahuan. Dosen juga harus berperan aktif dan efektif dalam pelaksanaan pendidikan agama Hindu, sehingga pembelajaran yang bermakna akan tercapai. Mahasiswa STAHN-TP Palangka Raya mengalami pemahaman yang cukup memuaskan, dalam memahami atau memaknai mata kuliah Tawur sesuai dengan tradisi masing-masing yang beragam di Kalimantan. Maksudnya, ada persamaan antara tradisi Dayak Kaharingan dan tradisi Bali mengenai upacara Tawur sebagai bentuk penyucian bhuwana alit dan bhuwana agung. Contohnya, pelaksanaan upacara Manyanggar/ Mamapas Lewu dalam tradisi Dayak Kaharingan dan upacara Mecaru dalam tradisi Bali yang dilaksanakan di Bundaran Besar, Palangka Raya setiap tahunnya. Hal tersebut sesuai dengan gambar 2.1 berikut ini.

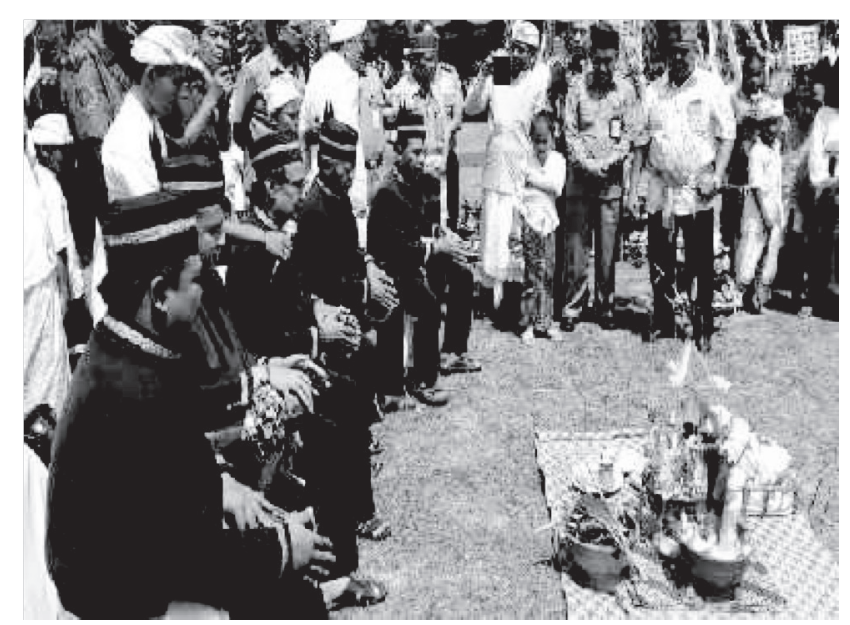

Gambar: 2.1

\subsection{Upacara Mamapas Lewu dan Mecaru di Palangka Raya}

Berdasarkan dari gambar tersebut, Upacara mamapas lewu dan Mecaru merupakan upacara keagamaan yang dilaksanakan oleh umat Hindu, pada saat sebelum membangun rumah/ bangunan suci dan lingkungan (desa), serta sebelum melewati pergantian tahun. Upacara tersebut dilaksanakan oleh umat Hindu secara rutin dan bersama-sama, contohnya pelaksanaan upacara mamapas lewu dan mecaru di Palangka Raya. Umat Hindu kota Palangka Raya berasal dari latar belakang etnis yang beragam yaitu Dayak, Bali, dan Jawa berbaur serta gotong royong dalam melaksanakan upacara mamapas lewu dan mecaru sebelum pergantian tahun. Pelaksanaan upacara tersebut terjadinya sinkretisme tradisi Kaharingan dan Bali dalam menyambut pergantian tahun melalui upacara bhuta yajna dengan memiliki tujuan yang sama. Walaupun memiliki ajaran dan tradisi yang berbeda, umat Hindu etnis Dayak, Bali, dan Jawa saling menjaga persatuan serta toleransi dalam melaksanakan suatu kegiatan upacara agama Hindu.

Upacara mamapas lewu/manyanggar dan mecaru adalah upacara bhuta yajna yang berfungsi untuk menetralisir dari pengaruh negatif dan untuk menjaga keseimbangan lingkungan secara sekala dan niskala. Senada dengan itu, menurut Karya (2013: 290) ritual Manyanggar dan Mecaru mengandung makna sebagai ungkapan rasa terima kasih manusia kepada Tuhan Yang Maha Esa, sesama makhluk hidup ciptaan-Nya, dan kepada alam/lingkungan sekitar. Karena alam telah memberikan manfaat multi guna kepada manusia. Manusia wajib memelihara, menjaga, dan melestarikan agar tetap terjaga keseimbangannya.

Konteksnya dalam pendidikan agama Hindu berbasis kearifan lokal Kaharingan di STAHN-TP Palangka Raya dapat diketahui dari kegiatan pembelajaran mata kuliah Tawur. Mata kuliah Tawur dapat digolongkan menjadi dua yaitu Tawur I dan Tawur II. Kegiatan pembelajaran dan materi mata kuliah Tawur I dan Tawur II tidak jauh berbeda. Tawur I lebih berfokus pada unsur teoretis dan Tawur II lebih berfokus pada unsur praktik. Berdasarkan Silabus dan SAP (Satuan Acara Pembelajaran), mata kuliah Tawur I dan Tawur II sebagai mata kuliah prasyarat memiliki beban studi masing-masing dua SKS (Sistem Kredit Semester). Hal ini sesuai dengan pernyataan Hendri (wawancara 25 Juli 
2017) berikut ini:

Kegiatan pembelajaran Tawur dilaksanakan pada hari Senin dan Selasa bagi mahasiswa jurusan Dharma Acarya semester ganjil (5,7, dan seterusnya). Semua mata kuliah lokal Kaharingan, termasuk Tawur ( I dan II) memiliki beban studi berjumlah dua SKS. Mata kuliah Tawur digolongkan menjadi dua yaitu Tawur I dan Tawur II untuk membagi materi dan waktu/ jam pelajaran supaya intensitasnya tidak terlalu padat. Biasanya Tawur I lebih banyak mempelajari tentang teori dari Tawur I dan Tawur II lebih banyak mempelajari tentang praktik upacaranya.

Berdasarkan dari kutipan tersebut, mata kuliah Tawur dan mata kuliah lokal Kaharingan lainnya dapat digolongkan menjadi dua. Contohnya Tawur I dan Tawur II. Tawur I dan Tawur II memiliki beban studi yang berjumlah dua SKS. Tawur I dan Tawur II memiliki karakteristik materi yang tidak berbeda jauh. Tawur I adalah bagian dari mata kuliah Tawur yang lebih berfokus pada unsur teori tentang upacara Tawur, seperti sejarah beras Tawur, pengertian tawur, dan hal-hal pendukung upacara tersebut. Tujuan umum dari Tawur I yaitu untuk memberikan pengetahuan dasar kepada mahasiswa STAHN-TP Palangka Raya mengenai nilai filosofi tawur dan hal-hal pendukung upacara keagamaan yang berhubungan dengan tawur. Tawur II adalah bagian dari mata kuliah Tawur yang lebih berfokus pada unsur praktik tentang upacara tawur, seperti perlengkapan dan persiapan manawur, mantra tawur dan hal-hal pendukung terlaksananya upacara tersebut. Tujuan umum dari Tawur II yaitu untuk melatih mahasiswa STAHN-TP Palangka Raya untuk mampu membuat sarana (upakara) dan mempraktikan upacara tawur, sesuai dengan teori yang disampaikan oleh dosen pengampu. Jadi, kegiatan pembelajaran mata kuliah Tawur I dan Tawur II memuat teori dan praktik yang seimbang.

Mata kuliah Tawur dan mata kuliah lokal Kaharingan lainnya memberikan suatu tantangan bagi dosen pengampu dan mahasiswa STAHN-TP Palangka Raya, dalam melaksanakan kegiatan pembelajaran. Karena, latar belakang mahasiswa terdiri dari DAS yang berbeda dan tradisi yang beragam di Kalimantan. Dosen pengampu mata kuliah Tawur juga berusaha untuk lebih mengeksplorasi dan mengembangkan kompetensi

dalam mengombinasikan ajaran dan tradisi Hindu Kalimantan yang beragam. Hal ini sesuai dengan pernyataan Komang Suarta dan Hendri (wawancara 1 Agustus 2017) berikut ini:

Mahasiswa STAHN-TP Palangka Raya berasal dari latar belakang daerah yang beragam di wilayah Kalimantan dan luar Kalimantan. Walaupun berbeda dalam pemahaman maknanya, pada intinya Tawur itu mempunyai tujuan yang hampir sama yaitu salah satunya sebagai media komunikasi kepada Sahur Parapah untuk upacara penyucian Bumi dengan pemahaman yang beragam. Kemudian adanya keberagaman tersebut, kami memberikan pemahaman dan sharing kepada mahasiswa terhadap mata kuliah Tawur. Walaupun memakai tradisi DAS Kahayan, mahasiswa sangat semangat dalam mengikuti pembelajaran di ruangan, terutama mahasiswa etnis Bali dan Jawa.

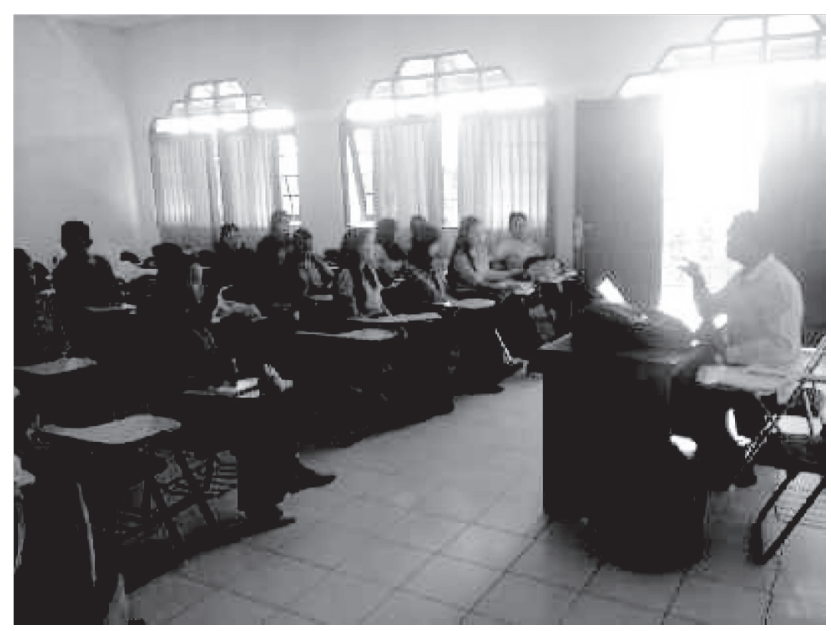

Gambar: 2.2

\subsection{Materi Pembelajaran Mata Kuliah Tawur}

Penerapan pembelajaran di jenjang pendidikan anak usia dini, dasar, menengah, dan tinggi tidak akan pernah terlaksana dengan baik, tanpa adanya suatu materi ajar/ pembelajaran. Materi merupakan salah satu komponen dari sistem pembelajaran yang mempunyai peran penting bagi peserta didik. Materi pembelajaran sangat membantu peserta didik untuk mencapai standar kompetensi dan kompetensi dasar yang telah ditetapkan pada rencana pembelajaran. Materi pembelajaran 
adalah isi dari bahan ajar yang memuat konsep, prinsip, definisi, proses, dan nilai dalam suatu mata pelajaran/mata kuliah. Materi yang dikembangkan pendidik hendaknya mengacu pada kurikulum dan penyampaiannya disesuaikan dengan kebutuhan dan lingkungan peserta didik. Hal ini sesuai dengan pendapat Hamdani (2011: 120) bahan ajar (materi) adalah segala bentuk bahan atau materi yang disusun secara sistematis yang digunakan untuk membantu guru atau instruktur dalam melaksanakan kegiatan belajar mengajar, sehingga tercipta suasana yang memungkinkan siswa untuk belajar.

Depdiknas (2008:3) menyatakan "materi pembelajaran secara garis besar terdiri dari pengetahuan, keterampilan, dan sikap yang harus dipelajari peserta didik dalam rangka memenuhi standar kompetensi yang telah ditentukan". Depdiknas melanjutkan, materi pembelajaran menempati posisi yang sangat penting dari keseluruhan kurikulum, yang harus dipersiapkan agar pelaksanaan pembelajaran dapat mencapai sasaran. Sasaran tersebut disesuaikan dengan standar kompetensi dan kompetensi dasar yang harus dicapai oleh peserta didik. Artinya, materi yang ditentukan untuk kegiatan pembelajaran adalah materi yang sejatinya menunjang tercapainya standar kompetensi dan kompetensi dasar, serta tercapainya indikator. Hal-hal yang perlu diperhatikan berkenaan dengan pemilihan materi pembelajaran adalah jenis, cakupan, urutan, dan perlakuan terhadap materi pembelajaran tersebut.

Mata kuliah Tawur dapat digolongkan menjadi dua bagian yaitu Tawur I dan Tawur II. Kedua golongan mata kuliah Tawur memuat materi pembelajaran yang disesuaikan dengan standar kompetensi, kompetensi dasar, kebutuhan mahasiswa, dan situasi pembelajaran. Hal tersebut sesuai dengan pernyataan Hendri dan Suarta (wawancara 1 Agustus 2017) beriktu ini :

Mata kuliah Tawur (I dan II) diperuntukkan bagi mahasiswa STAHN-TP Palangka Raya semester V dan VI atau mahasiswa yang tidak lulus dan cuti. Mata kuliah ini juga memiliki standar kompetensi dan kompetensi dasar. Standar kompetensi adalah pengetahuan, kemampuan, dan sikap yang harus dikuasai mahasiswa. Hasil yang dicapai dari proses pembelajaran mahasiswa dalam menempuh suatu mata kuliah tertentu. Pada Tawur I proses pembelajarannya lebih banyak teori daripada praktik. Tawur II, jika dilihat dari materinya lebih banyak praktik daripada teori, karena disana memuat sarana upacara dan pelaksanaan upacara dalam menawur. Tetapi, saya dapat mengkombinasikan teori dan praktik tergantung dengan materi pembelajaran pada mata kuliah Tawur dan situasi/kebutuhan mahasiswa.

Pada hakikatnya Tawur sebagai mata kuliah prasyarat diperlukan adanya keseimbangan antara teori dan praktik. Mata kuliah Tawur biasanya diidentikan lebih mengutamakan praktik daripada teori dalam proses pendidikan di STAHN-TP Palangka Raya. Karena, Tawur adalah rangkaian kegiatan upacara keagamaan Hindu Kaharingan di Kalimantan Tengah. Tetapi, teori dan praktik seharusnya seimbang dalam suatu penerapan pendidikan di perguruan tinggi Hindu yang bersifat upacara keagamaan. Teori diperlukan untuk menjelaskan hal-hal pokok yang perlu diketahui dan dilaksanakan kepada mahasiswa; seperti pengertian Tawur, sejarah beras Tawur, mantra yang digunakan, sarana dan prasarana, syarat-syarat dalam manawur, dan lain-lain. Menurut Hendri (2015: 1) ada beberapa unsur dalam standar kompetensi yang harus mahasiswa STAHN-TP Palangka Raya kuasai, dalam menempuh mata kuliah Tawur I dan Tawur II, berikut ini:

Pada akhir perkuliahan mahasiswa mampu memahami; sejarah asal usul beras tawur, proses penciptaan beras tahap pertama, proses penciptaan beras tahap kedua, pengertian tawur, fungsi tawur, peranan tawur, jenis tawur, penggunaan tawur, jenis upacara yang menggunakan tawur, persiapan dan perlengkapan manawur, mantram tawur, dan pelaksanaan tawur.

Agama Hindu memiliki tiga kerangka dasar yaitu filsafat, etika, dan ritual sebagai pedoman manusia Hindu dalam menjalani kehidupannya di dunia yang berlandaskan dharma. Kaharingan sebagai agama Hindu lokal Kalimantan, juga memiliki ketiga kerangka tersebut yang memiliki persepsi beragam masing-masing daerah di Kalimantan. Mahasiswa STAHN-TP Palangka Raya adalah generasi Hindu yang perlu mengetahui, memahami,dan melaksanakan filsafat, etika, dan ritual secara seimbang, dalam mencapai standar kompetensi pada mata kuliah 
Tawur. Sehingga nantinya tidak menimbulkan fanatisme berlebihan tentang ajaran dan tradisi Hindu lokal di daerah masing-masing.

Dilihat dari aspek ritualnya, mata kuliah Tawur selalu menggunakan beras sebagai media/sarana dalam pelaksanaan upacara keagamaan Hindu Kaharingan di Kalimantan Tengah. Beras tidak hanya dipakai pada saat pelaksanaan upacara Manawur, melainkan semua upacara keagamaan Hindu Kaharingan dari lingkup sempit hingga luas seperti; upacara kelahiran, kehidupan, dan kematian. Menurut kepercayaan umat Hindu Kaharingan, beras memiliki makna yang luas bagi kehidupan sehari-sehari. Karena beras selain digunakan bahan pangan sehari-hari, juga berfungsi sebagai sarana utama pada kegiatan upacara keagamaan. Hal tersebut sesuai dengan pernyataan Komang Suarta dan Hendri (wawancara 5 Agustus 2017) berikut ini:

Beras dalam bahasa Sangiang disebut behas parei manyangen tingang, pulut lumpang penyang. Beras juga diyakini oleh umat Hindu Kaharingan, karena memiliki roh atau kekuatan spiritual yang dapat menjadi media penghubung manusia dengan para Dewa yang termuat pada mantra Tawur. Raja Bunu sebagai leluhur manusia di bumi, tidak bisa sehat memakan pantar pinang, walaupun ia memakannya tidak bisa menjadi darah dagingnya seperti kedua saudaranya yaitu Raja Sangiang dan Raja Sangen. Kemudian Ranying Hatalla memberikan sebuah guci lalang tambangap langit yang berisi Behas manyangen tingang dan Dendeng lauk ilai-ilai langit kepada orang tua Raja Bunu agar ia bisa tumbuh sehat.

Berdasarkan dari kutipan tersebut, secara filosofis beras memiliki makna yang mendalam bagi umat Hindu Kaharingan di Kalimantan Tengah. Menurut ajaran Kaharingan, Raja Bunu adalah leluhur umat manusia yang berasal dari Pantai Danum Sangiang dan akan mengalami kematian dalam perjalanan hidupnya di Pantai Danum Kalunen (Bumi). Raja Bunu juga memiliki perbedaan yaitu tidak bisa mengonsumsi pantar pinang, bila dibandingkan dengan saudaranya yaitu Raja Sangiang dan Raja Sangen. Kemudian kedua orang tua mereka yaitu Manyamei
Tunggul Garing dan Kameluh Putak Bulau meminta pertolongan kepada Ranying Hatalla Langit, agar Raja Bunu bisa tumbuh sehat seperti kedua saudaranya. Kemudian, Ranying Hatalla menciptakan behas manyangen tingang dengan menjalani proses dan akhirnya tercipta beras sebagai makanan bagi Raja Bunu serta keturunannya. Sebab itu, umat Hindu Kaharingan menggunakan beras hingga menjadi nasi sebagai bahan pangan dalam kehidupan sehari-hari. Pada hakikatnya manusia dalam mengonsumsi suatu makanan tidak hanya menggunakan nasi semata, melainkan juga menggunakan sayur atau ikan/daging sebagai pelengkap dari makanan tersebut.

Berdasarkan dari uraian sebelumnya, umat Hindu Kaharingan mengunakan beras sebagai salah satu media penghubung kepada para Ranying Hatalla beserta manifestasiNya dalam pelaksanaan upacara keagamaan. Mahasiswa STAHN-TP Palangka Raya dituntut untuk mengetahui dan memahami sejarah beras sebagai salah sarana upacara keagamaaan Hindu Kaharingan, dalam menempuh mata kuliah Tawur dan mata kuliah lokal Kaharingan lainnya. Sehingga, mahasiswa STAHN-TP Palangka Raya memiliki kompetensi secara teori dan praktik.

Mahasiswa STAHN-TP Palangka Raya dalam menempuh mata kuliah Tawur perlu mengetahui dan memahami aspek teori, disamping mampu mengimplementasi praktiknya di lapangan. Tawur memiliki beberapa fungsi yaitu komunikasi dan keharmonisan. Pertama komunikasi, mahasiswa dituntut untuk mengetahui dan memahami fungsi tawur sebagai cara untuk berkomunikasi kepada Ranying Hatalla beserta manifestasi-Nya, contohnya memohon ijin bahwa umat Hindu Kaharingan akan melaksanakan suatu upacara keagamaan. Kedua keharmonisan, mahasiswa dituntut untuk mengetahui dan memahami fungsi tawur sebagai cara untuk meminta petunjuk, keselamatan, dan kesembuhan kepada Ranying Hatalla beserta manifestasi-Nya.

Pelaksanaan upacara keagamaan Hindu Kaharingan terdapat beberapa komponen penting yang perlu disiapkan, salah satunya sarana (sesaji) dan perlengkapan upacara. Mahasiswa STAHN-TP Palangka Raya dituntut untuk mengetahui dan memahami sarana dan perlengkapan dalam manawur. Menurut Hendri 
(2016: 13) ada beberapa perlengkapan yang harus disiapkan dalam upacara manawur, yaitu sebagai berkut:

1) Amak (tikar).

2) Tambak behas dan sipa ruku (Sangku/ mangkuk besar dan rokok).

3 Mangkuk kecil untuk beras.

4) Garu manyan dan parapen ( Perapian/ dupa dan kemenyan ).

5) Tampung tawar ( air suci).

6) Behas tawur, (beras) ada empat jenis beras, yaitu beras dicampur darah, beras dicampur kunyit, beras dicampur emas dan perak, serta beras biasa (putih). Hal ini tergantung dengan upacara tawur yang akan dilaksanakan.

7) Sesaji seperti telur ayam, ayam, babi, sapi, kerbau (tergantung dengan upacara yang dilaksanakan).

8) Kasan undus ( minyak kelapa ).

9) Pakaian adat.

Hendri (2016: 14) melanjutkan bahwa sarana dan perlengkapan upacara manawur secara umum memiliki perbedaan. Karena masingmasing upacara memiliki makna dan tujuan upacara yang berbeda. Adapun sarana dan perlengkapan yang utama dalam upacara manawur yaitu behas tawur, purun/amak, tampung tawar, sesaji, kasan undus, dan mangkuk kecil. Hal ini disiapkan supaya dalam pelaksanaannya tidak mengalami berbagai halangan. Mahasiswa STAHN-TP Palangka Raya diharapkan dan dituntut untuk memiliki kompetensi mengenai sarana dan perlengkapan upacara manawur dalam tradisi DAS Kahayan. Sarana dan perlengakapan upacara manawur tidak seluruhnya sama, karena tergantung dengan tradisi daerah dan tujuan dari upacara tersebut.

Mantra selalu diucapkan atau dilantunkan oleh para rohaniawan dalam pelaksanaan upacara keagamaan Hindu. Pelaksanaan tawur juga terdapat mantramantra sebagai penunjang kegiatan upacara tersebut. Mahasiswa STAHNTP Palangka Raya dituntut untuk mampu mengetahui, mengingat, dan mengucapkan/ melantunkan mantra-mantra tawur dalam upacara keagamaan Hindu Kaharingan. Salah satu mantra yang terdapat dalam upacara keagamaan Hindu

Kaharingan, dapat dijelaskan pada kitab
Panaturan pada pasal 42 ayat 1 dan 2 (dalam Hendri, 2016: 18) berikut ini :

Ehem-ehem behas pararinjet ganam, kilau lunuk randan pakungan tingang pararuguh labatam tapang ringkang pasanan antang.

Ela bitim tarewen matei kalabuan jaringku nduan ambun andau etuh, isen balitam sabanen nihau kalapeten karahku matuk dinun kalamau ketun.

Terjemahan:

Bangunlah Roh kekuatan kemaha
kuasaan-Mu dari badan tempat
tinggalMu.
Jangan engkau terkejut keluar dari ujung
jari tanganku saat ini.

Mantra-mantra tawur yang terdapat pada pelaksanaan upacara Hindu Kaharingan memiliki tujuan yang beragam. Mahasiswa STAHN-TP Palangka Raya juga dituntut untuk memiliki kompetensi dalam memahami makna yang terkandung dalam mantra tersebut. Tata cara dalam mengucapkan/melantunkan mantra-mantra tawur harus dilakukan sesuai prosedur yang diarahkan oleh rohaniawan. Karena tanpa adanya prosedur yang sesuai, hambaruan individu yang mengucapkan/ melantunkan mantra tawur akan mengalami hal-hal yang kurang baik.

Agama Hindulebih dikenal dan dipublikasikan melalui upacara keagamaan. Upacara dapat dianalogikan sebagai kulit luar telur yang tipis dan melindungi bagian daging serta inti telur. Maksudnya, bahwa dunia melihat agama Hindu yang unik dan indah berdasarkan tradisi lokal melalui upacara keagamaan. Unsur etika dan filsafat Hindu jarang dipublikasikan kepada publik. Karena, menurut persepsi masyarakat awam upacara keagamaan Hindu lebih menonjolkanunsurestetika. Pada pelaksanaanya tawur dapat dibagi beberapa macam jenis upacara sesuai dengan tujuan dan fungsi masing-masing.

Menurut Mariatie (dalam Hendri, 2009: 107) bahwa tawur terdiri atas dua bagian yakni tawur untuk keselamatan, tawur untuk kematian. Kemudian, menurut Hendri (2009: 107) tawur untuk keselamatan disebut Putir Bawin Tawur dan tawur untuk kematian disebut Manyamei Hatuen Tawur. Putir Bawin Tawur digunakan untuk upacara pakanan patahu, nahunan, 
nyadiri, balaku untung, manajah antang, pakanan sahur. Tujuan tawur tersebut adalah untuk memohon keselamatan hidup. Manyamei Hatuen Tawur digunakan untuk upacara penguburan, tantulak ambun rutas matei, dan tiwah. Mahasiswa STAHN-TP Palangka Raya dituntut untuk mampu mengetahui, memahami, dan mempratikan upacara-upacara Hindu Kaharingan yang menggunaan tawur. Tetapi, mahasiswa dalam mempelajari

Manyamei Hatuen Tawur tidak diwajibkan mempraktikan semua upacara yang ada. Mahasiswa bisa diarahkan untuk membuat atau membawa sarana dan perlengkapan yang sederhana. Materi mata kuliah Tawur I dan Tawur II menggunakan ajaran dan tradisi dari DAS Kahayan. Karena, lokasi STAHN-TP Palangka Raya berada di wilayah aliran sungai Kahayan, Kalimatan Tengah. Mahasiswa STAHN-TP Palangka Raya yang berasal dari latar belakang DAS dan etnis yang beragam memperoleh pengetahuan baru tentang tradisi Hindu Kaharingan yang berasal dari DAS Kahayan. Mahasiswa yang memprogramkan mata kuliah Tawur (I dan II) dituntut untuk mempelajari dan memiliki kompetensi terkait mata kuliah tersebut. Walaupun mahasiswa STAHN-TP Palangka Raya memiliki ajaran dan tradisi yang beragam di Kalimantan. Hal tersebut diharapkan mahasiswa dapat mengonstruksikan pengetahuan baru yang diperoleh di kampus dengan pengetahuan di daerah asal masingmasing. Karena diakibatkan dari interaksi secara intensif antara dosen mata kuliah Tawur dan sesama mahasiswa STAHN-TP Palangka Raya.

\subsection{Metode Pembelajaran Mata Kuliah Tawur}

Menurut Suyono dan Hariyanto (2015: 91) metode pembelajaran adalah seluruh perencanaan dan prosedur maupun langkahlangkah kegiatan pembelajaran, terkait dengan pilihan cara penilaian yang akan dilaksanakan. Sedangkan menurut Hamdani (2011: 80) metode pembelajaran adalah cara yang digunakan guru untuk menyampaikan pelajaran kepada siswa. Berdasarkan dari pengertian tersebut dapat disimpulkan bahwa metode pembelajaran adalah kumpulan cara yang digunakan oleh pendidik untuk mencapai tujuan pembelajaran, melalui rencana pembelajaran dan memperhatikan situasi atau kondisi peserta didik.

Tenaga pendidik dapat dianalogikan sebagai seorang "manajer" (pemimpin) dalam meramu semua komponen pendidikan yaitu sarana dan prasarana, kurikulum, dan peserta didik. Tugas dari pendidik tidak hanya berperan selayaknya sebagai "bos" yang memberikan doktrin atau perintah, melainkan lebih menekankan pada memberikan pemahaman, motivasi, dan tindakan inspiratif kepada peserta didik. Hakikatnya seorang pendidik(dosen) menguasai metode pembelajaran, disamping memiliki kompetensi terhadap materi pembelajaran. Metode-metode yang digunakan oleh pendidik dalam proses pembelajaran di ruang kelas, tidak ada yang bersifat lebih unggul atau lebih buruk dari metode lainnya. Hal itu tergantung pada situasi, materi pembelajaran, dan kebutuhan peserta didik. Penggunaan metode pembelajaran tidak hanya berfokus pada satu metode. Pendidik perlu menggunakan metode yang bervariasi pada satu sesi pembelajaran di kelas. Setiap metode juga memiliki kekuatan dan kelemahan masing-masing. Inovasi pendidik juga sangat berperan untuk menanggulangi kelemahan tersebut dan membuat kelas menjadi lebih aktif serta bersemangat dalam proses pembelajaran.

Pendidikan agama Hindu berbasis kearifan lokal Kaharingan juga diperlukan sebuah metode yang digunakan dalam proses pembelajaran kepada mahasiswa STAHN-TP Palangka Raya. Mata kuliah lokal Kaharingan, contohnya Tawur yang memiliki keunikan tersendiri, jika dibandingkan dengan mata kuliah inti dari suatu kurikulum perguruan tinggi Hindu di Indonesia. Keunikan tersebut diperlukan suatu metode yang tepat, disamping tersedianya bahan pembelajaran, materi, dan dosen yang berkompeten untuk mencapai tujuan yang telah direncanakan. Senada dengan itu, menurut Suasta (2009: 99) pentingnya memilih sebuah metode yang akan digunakan dalam proses pembelajaran adalah metode memiliki peranan yang bisa digunakan untuk mengimplementasikan rencana yang sudah disusun dalam kegiatan nyata pembelajaran agar tujuan yang telah disusun tercapai secara optimal.

Penerapan pendidikan agama Hindu berbasis kearifan lokal Kaharingan di STAHNTP Palangka 
Raya menekankan pada proses dan kebebasan dalam menggali pengetahuan serta mengonstruksi pengalaman-pengalaman mahasiswa di daerah asal atau di lingkungan kampus. Adanya metode pembelajaran yang tepat, kreativitas dosen, dan partisipasi mahasiswa yang baik, sehingga terlaksananya standar kompetensi mata kuliah lokal Kaharingan khususnya Tawur. Hal tersebut senada dengan pernyataan Hendri (wawancara 25 Juli 2017) berikut ini:

Saya menggunakan beberapa metode dalam proses pembelajaran mata kuliah Tawur (I dan II) di semester V dan VI yang disesuaikan dengan tradisi DAS Kahayan yaitu metode ceramah, tanya jawab, dan latihan (praktik). Mahasiswa STAHN-TP Palangka Raya berasal dari latar belakang daerah yang beragam di wilayah Kalimantan dan luar Kalimantan. Mereka ratarata tahu mengenai Tawur dalam bentuk upacara. Walaupun dengan nama, mantra, pemahaman, dan bahasa yang berbeda. Kemudian adanya keberagaman tersebut, saya memberikan pemahaman dan sharing kepada mahasiswa terhadap mata kuliah Tawur, dan melalui metode-metode tersebut pengetahuan baru serta pemahaman mahasiswa terbentuk.

Walaupun saya memakai tradisi DAS Kahayan, mahasiswa sangat semangat dalam mengikuti pembelajaran di ruangan, terutama mahasiswa etnis Bali dan Jawa. Setelah itu saya juga mendatangkan beberapa rohaniawan untuk memberikan praktik upacara Tawur kepada mahasiswa.

Berdasarkan dari kutipan tersebut, dosen pengampu mata kuliah Tawur menyesuaikan dengan standar kompetensi dari SAP (Satuan Acara Pembelajaran) dalam menerapkan metode pembelajaran. Dosen pengampu dominan menggunakan metode ceramah pada mata kuliah Tawur I. Karena, standar kompetensi yang tercantum pada SAP mata kuliah Tawur I, menjelaskan bahwa mahasiswa diarahkan agar mampu mengetahui, memahami, dan menerapkan nilai-nilai atau lebih mengarah ke hal yang bersifat teoretis. Kemudian dosen pengampu dominan menggunakan metode latihan (praktik) dan metode tanya jawab pada penerapan mata kuliah Tawur II. Karena, standar kompetensi yang tercantum pada SAP mata kuliah Tawur II lebih memfokuskan hal-hal yang bersifat praktik.
Mahasiswa STAHN-TP Palangka Raya memiliki ajaran dan tradisi agama Hindu yang beragam pada kehidupannya sehari-hari. Walaupun mayoritas mahasiswa berasal dari etnis Dayak, tidak dapat disamakan ajaran dan tradisi masing-masing. Karena, setiap DAS atau daerah di Kalimantan memiliki kearifan lokal yang beragam. Mahasiswa STAHN-TP Palangka Raya juga berasal dari etnis Bali dan Jawa. Tradisi Bali dan Jawa juga memiliki ajaran dan tradisi yang hampir sama mengenai mata kuliah Tawur. Namun dengan nama, bahasa, dan pemahaman yang berbeda. Adanya berbagai metode yang digunakan oleh dosen pengampu mata kuliah Tawur, mahasiswa sangat antusias dan membangun pengetahuan, serta pengalaman baru mengenai mata kuliah Tawur di STAHN-TP Palangka Raya.

Penerapan pendidikan agama Hindu berbasis kearifan lokal Kaharingan di STAHN-TP Palangka Raya, tidak hanya menekankan pada aspek kognitif terhadap mahasiswa. Penilaian afektif dan psikomotor juga berperan dalam penerapan proses pembelajaran, khususnya pada mata kuliah Tawur di STAHN-TP Palangka Raya. Hal tersebut, sesuai dengan pendapat Bloom (dalam Sagala, 2010: 33) tujuan pendidikan dibagi menjadi tiga taksonomi yaitu domain kognitif, domain afektif, dan domain psikomotor. Bloom melanjutkan, belajar adalah perubahan kualitas kemampuan kognitif, afektif, dan psikomotorik untuk meningkatkan taraf hidupnya

(mahasiswa) sebagai pribadi, masyarakat, dan makhluk Tuhan Yang Maha Esa. Metode yang digunakan pada penerapan pembelajaran mata kuliah Tawur juga menerapkan taksnomi Bloom dan sangat membantu mahasiswa STAHN-TPPalangkaRayauntukmengembangkan potensi dan kompetensi dalam mengetahui, memahami, serta menerapkan pengetahuan agama Hindu berbasis kearifan lokal Kaharingan. Hal tersebut sesuai dengan pernyataan Ni Made Sudharmi dan Melky Setiawan (wawancara 1 Agustus 2017) berikut ini:

Dosen pengampu mata kuliah Tawur dan mata kuliah lokal Kaharingan lain, biasanya lebih sering memakai metode ceramah, kelompok, dan praktik. Berdasarkan metode tersebut, kami juga mengetahui apa itu Tawur, bagaimana tata cara manawur yang baik dan benar, apa saja sarana dan prasarana upacara Tawur, bagaimana mantra Tawur, dan lain-lain. 
Sebenarnya kami lebih paham tentang materi mata kuliah lokal ini, ketika menggunakan metode praktik dan adanya partisipasi rohaniawan dalam pembelajaran. Walaupun kami berbeda tradisi dalam memahami mata kuliah atau upacara Tawur, itu tidak mengurangi semangat untuk mempelajari dan menerapkannya di lingkungan masyarakat, agar kami tahu seperti apa tradisi keagamaan yang dimiliki sesama mahasiswa.Kami juga dituntut untuk bisa, tidak hanya dalam aspek pengetahuan semata, tetapi juga dalam aspek sikap dan keterampilan. Karena, di lingkungan masyarakat ketiga aspek tersebut sangat diperlukan.

\section{PENUTUP}

Kearifan lokal Kaharingan merupakan harta yang tidak ternilai bagi umat Hindu Kaharingan untuk dilestarikan ke generasi selanjutnya, agar tidak terkikis oleh waktu dan kebudayaan dari luar.STAHN-TP Palangka Raya sebagai Perguruan Tinggi Hindu mempunyai kewajiban yaitu melestarikan ajaran dan tradisi lokal Kaharingan melalui pendidikan agama Hindu di Kalimantan Tengah.

Mata kuliah Tawur dapat digolongkan menjadi dua bagian yaitu Tawur I dan Tawur II. Kedua golongan mata kuliah Tawur memuat materi pembelajaran yang disesuaikan dengan standar kompetensi, kompetensi dasar, kebutuhan mahasiswa, dan situasi pembelajaran. Pada akhir perkuliahan diharapkan mahasiswa mampu memahami; sejarah asal usul beras tawur, proses penciptaan beras tahap pertama, proses penciptaan beras tahap kedua, pengertian tawur, fungsi tawur, peranan tawur, jenis tawur, penggunaan tawur, jenis upacara yang menggunakan tawur, persiapan dan perlengkapan manawur, mantram tawur, dan pelaksanaan tawur.

STAHN-TP Palangka Raya memahami terhadap potensi kearifan lokal Kaharingan di Kalimantan, dalam merancang dan mengimplementasikan suatu kurikulum penciri (lokal) sebagai pendamping kurikulum umum seperti pada Perguruan Tinggi Hindu di Indonesia. Kurikulum penciri tersebut melahirkan tujuh mata kuliah lokal Kaharingan yang dilaksanakan pada pendidikan agama Hindu di STAHN-TP Palangka Raya. Isi dari muatan lokal di STAHN- TP Palangka Raya adalah mata kuliah yang berkaitan dengan kearifan lokal atau ajaran dan tradisi Dayak Kaharingan. Mata kuliah tersebut yaitu Panaturan, tawur, tandak, bahasa Sangiang, acara agama Hindu Kaharingan, bahasa daerah (Dayak Ngaju), dan theologi Hindu Kaharingan.

\section{DAFTAR PUSTAKA}

Anonim. 2005. Buku Pedoman Sekolah Tinggi Agama Hindu Negeri Tampung Penyang Palangka

Raya. Palangka Raya: Sekolah Tinggi Agama Hindu Negeri Tampung Penyang.

Anonim. 2008. Buku Pedoman Sekolah Tinggi Agama Hindu Negeri Tampung Penyang Palangka

Raya. Palangka Raya: Sekolah Tinggi Agama Hindu Negeri Tampung Penyang.

Anonim. 2008. Kamus Besar Bahasa Indonesia Pusat Bahasa. Jakarta: Gramedia Pustaka Utama.

Arikunto, Suharsimi. 2006. Dasar-dasar Evaluasi Pendidikan. Jakarta: Bumi Aksara.

Bagong \& Sutinah. 2005. Metode Penelitian Sosial. Jakarta: Kencana.

Buhol, dkk. 2016. Panaturan (sebagai pedoman hidup umat Hindu Kaharingan). Palangka Raya:

Sekolah Tinggi Agama Hindu Negeri Tampung Penyang.

Depdiknas. 2008. Panduan Pengembangan Materi Pembelajaran. Jakarta: Depdiknas.

Edung, Tardi. 2008. "Studi Evaluasi Kurikulum Muatan Lokal di Sekolah Tinggi Agama Hindu Negeri

Tampung Penyang Palangka Raya". Tesis ( tidak diterbitkan). Denpasar: Program

Pascasarjana Institut Hindu Dharma Negeri.

Hamdani. 2011. Strategi Belajar Mengajar. Bandung: Pustaka Setia.

Hendri. 2009. "Tawur Masyarakat Hindu Kaharingan sebagai Media Komunikasi dengan Ranying Hatalla di Kota Palangka Raya". Tesis (tidak diterbitkan ). Denpasar: Program Pascasarjana Universitas Hindu Indonesia. 
Hendri. 2012. Jurnal Tampung Penyang. Volume X. Nomor 2 Edisi Agustus 2012.

Sekolah Tinggi Agama Hindu Negeri Tampung Penyang Palangka Raya.

Hendri. 2015. Silabus dan Satuan Acara Perkuliahan Tawur I dan Tawur II. Palangka Raya: Sekolah Tinggi Agama Hindu Negeri Tampung Penyang.

Hendri, dkk. 2016. Tawur dalam Agama Hindu Kaharingan. Palangka Raya: Sekolah Tinggi Agama Hindu Negeri Tampung Penyang.

Idi, Abdullah. 2010. Pengembangan Kurikulum Teori dan Praktik. Yogyakarta: ArRuzz Media.

Kadir, Abdul, dkk. 2012. Dasar-dasar Pendidikan. Jakarta: Kencana.

Karya, I Wayan. 2009. "Integrasi Kepercayaan Masyarakat Kaharingan dengan Agama Hindu di Kalimantan Tengah". Tesis ( tidak diterbitkan). Denpasar: Program Pascasarjana Universitas Hindu Indonesia.

Karya, I Wayan. 2013. “Interaksi Budaya dalam Manyanggar dan Mecaru Masyarakat Hindu Kaharingan dengan Masyarakat Hindu Asal Bali". Disertasi (tidak diterbitkan). Malang: Program Pascasarjana Universitas Merdeka.

Pranata, dkk. 2009. Upacara Ritual Perkawinan Agama Hindu Kaharingan. Surabaya: Paramita.

Puspe, I Made. 2012. "Pembelajaran Pendidikan Agama Hindu Di Sekolah Tinggi Agama Hindu Negeri Tampung Penyang Palangka Raya. Tesis. ( tidak diterbitkan). Denpasar: Program Pascasarjana IHDN.

Raho, Bernard. 2007. Teori Sosiologi Modern. Jakarta: Prestasi Pustaka.

Ratna, Nyoman Kutha. 2013. Glosarium 1250 Entri Kajian Sastra, Seni, dan Sosial Budaya. Yogyakarta: Pustaka Pelajar.

Ridwan. 2004. Metode dan Teknik Menyusun Tesis. Bandung: Alfabeta.

Riwut, Tjilik. 2007. Kalimantan Membangun Alam dan Kebudayaan. Yogyakarta: NR Publishing. Sagala, Syaiful. 2010. Konsep dan Makna Pembelajaran, cet. 8. Bandung: Alfabeta.

Sanjaya, Putu. 2011. Filsafat Pendidikan Agama Hindu. Surabaya: Paramita.

Suarta, Komang. 2012. Jurnal Tampung Penyang. Volume X. Nomor 2 Edisi Agustus 2012. STAHN-TP Palangka Raya.

Suasta, I Wayan. 2009. “Pembelajaran Agama Hindu Berwawasan Multikultural di Sekolah Tinggi Agama Hindu Negeri Tampung Penyang Palangka Raya" Tesis (tidak diterbitkan). Denpasar: Program Pascasarjana IHDN.

Suasta, I Wayan. 2016. "Pendidikan Agama Hindu Berbasis Multikultural pada Masyarakat Suku Dayak Di Kota Palangka Raya”. Disertasi ( tidak diterbitkan). Denpasar: Program Pasca Sarjana IHDN.

Sugiyono. 2009. Metode Penelitian Kuantitatif Kualitatif dan R\&D. Bandung:Aksara 